\section{Interação dos Glicoalcalóides Sola- náceos com Drogas Utilizadas em Anestesia}

Senhor Editor,

Venho através desta encaminhar comentário referente ao tema "Interação dos Glicoalcalóides Solanáceos com Drogas Utilizadas em Anestesia" publicado na Rev Bras Anestesiol, 2002;52:382, de autoria da Dra. Eugesse Cremonesi. O tema realmente desperta interesse em uma área não muito estudada pelos anestesiologistas mas que apresenta um grande potencial de interações com a nossa prática ${ }^{1}$. O referido estudo foi realizado em coelhos com testes in vitro e in vivo, com redução dos níveis de butirilcolinesterase e prolongamento da duração do bloqueio neuromuscular com mivacúrio, artigo publicado recentemente na íntegra no mesmo periódico ${ }^{2}$. Nesta mesma linha, não somente alimentos mas também outras drogas podem interferir na farmacocinética ou farmacodinâmica dos relaxantes neuromusculares. Ostergaard e col. demostraram que após o uso pré-operatório de um broncodilatador oral houve um aumento significativo (3 a 4 vezes) na duração de ação do mivacúrio ${ }^{3}$. A pergunta que fica é se estes resultados apresentados em animais podem ser reproduzidos em seres humanos. Em estudo piloto Johanns e Mensinga ${ }^{4}$ demonstraram em voluntários que a administração oral de glicoalcalóides não provocou diminuição das concentrações séricas de colinesterase. $O$ fato ainda deixa em aberto a resposta, que somente estudos futuros poderão esclarecer. Aproveitamos a oportunidade para enviar-Ihe nossos préstimos de estima e consideração.

Atenciosamente.

Dr. Pedro Paulo Tanaka, TSA

Rua Justiniano de Mello e Silva, 355

82530-150 Curitiba, PR

E-mail: tanaka@bsi.com.br

\section{Interaction of Solanaceous Glycoalka- loids with Anesthetic Drugs}

Mr. Editor,

This is to forward a comment on the subject "Interaction of Solanaceous Glycoalkaloids with Anesthetic Drugs", published in the Brazilian Journal of Anesthesiology, 2002;52:382, by Dra. Eugesse Cremonesi.

In fact, the subject raises interest in an area not thoroughly studied by anesthesiologists, but with a major interaction potential in our practice ${ }^{1}$. The above-mentioned study was performed in rabbits with in vitro and in vivo tests, with decreased butyrilcholinesterase levels and prolonged neuromuscular block with mivacurium, article recently published in the same journal ${ }^{2}$.

Along the same lines, not only food, but also other drugs may interfere with neuromuscular relaxants pharmacokinetics or pharmacodynamics. Ostergaard et al. have shown that after the preoperative use of a bronchodilator, there has been a significant increase ( 3 to 4 times) in mivacurium duration ${ }^{3}$. In a pilot study in humans, Johanns and Mensinga ${ }^{4}$ have shown in volun- teers that the oral administration of glycoalkaloids has not decreased cholinesterase serum concentrations. This is an open subject, which only further studies may explain.

Yours sincerely.

Pedro Paulo Tanaka, TSA, M.D.

Rua Justiniano de Mello e Silva, 355

82530-150 Curitiba, PR

E-mail: tanaka@bsi.com.br

\section{REFERÊNCIAS - REFERENCES}

01. Krasowski MD, McGehee DS, Moss J - Natural inhibitors of cholinesterase: implications for adverse drug reactions. Can J Anaesth 1997;44:525-534.

02. McGehee DS, Krasowski MD, Fung DL et al - Cholinesterase inhibition by potato glycoalkaloids slows mivacurium metabolism. Anesthesiology, 2000;93: 510-519.

03. Ostergaard D, Rasmussen S, Viby-Mogensen J et al - The influence of drug-induced cholinesterase activity on the pharmacokinetics and pharmacodynamics of mivacurium. Anesthesiology, 2000;92: 1581-1587.

04. Johanns E, Mensinga T - Clinical pilot study on the bioavailability of glycoalkaloids from potato. RIVM report 388802 020. National Institute of Public Health and the Environment, Netherlands, 2001.

\section{Meningite após Técnica Combinada para Analgesia de Parto. Relato de Caso}

Senhor Editor,

Considerando-se a importância dos autores, é oportuna a publicação "Meningite após Técnica Combinada para Analgesia de Parto. Relato de Caso", devido à generalização, com o risco de banalização desta técnica no nosso país, com o que não concordamos, inclusive recebendo o rótulo de técnica de analgesia mais próxima da ideal e colocando-se publicamente a peridural contínua segmentar com emprego de anestésico local associado a drogas opióides como técnica ultrapassada de analgesia para o trabalho de parto.

Consideramos "fantástico" o imediato alívio das dores provocadas pelas contrações uterinas após a injeção subaracnóidea das drogas opióides, seguida de excelente analgesia sem a ocorrência de bloqueio motor. Contudo por vários motivos não elegemos neste departamento a técnica combinada como $1^{\text {a }}$ opção para analgesia da $1^{\mathrm{a}}$ fase do trabalho parto, visto que indicamos a peridural contínua segmentar com anestésico local associado aos opióides ${ }^{1-3}$, tendo sido realizadas 56.925 analgesias desde 1.965, sem a ocorrência de nenhum caso de meningite. A literatura sugere que a técnica combinada proporciona analgesia efetiva mas é insuficiente para avaliar a eficácia analgésica quando comparada à peridural com anestésico local ${ }^{4}$ e que a incidência de operações cesarianas e de partos instrumentais são semelhantes ${ }^{5}$.

Prurido intenso ${ }^{5}$, hipotensão arterial e bradicardia fetal ${ }^{6,7}$, depressão respiratória ${ }^{8}$, altos níveis de bloqueio sensitivo atingindo até a região facial ${ }^{9}$, são complicações e/ou efeitos colaterais descritos recentemente na literatura com o emprego da técnica combinada, embora potencialmente estas alterações possam ocorrer com a tradicional peridural segmentar. 
Mas o principal obstáculo que colocamos para a adoção da técnica combinada, a qual poderia ser indicada para analgesia do trabalho de parto quando a dilatação do colo uterino fosse incipiente, continua sendo a maior possibilidade de infecção do sistema nervoso central, corroborada por esta publicação, quando se utiliza esta técnica mais invasiva ${ }^{5,10-13}$

Segundo conclusão do relato em discussão se não houver faIhas na realização da técnica combinada a questão tornar-se-ia simplesmente inerente ao risco benéfico da técnica. Sugerimos aos adeptos da técnica combinada, que informem as parturientes sobre os potenciais riscos e benefícios das duas técnicas discutidas e desde que se opte pela raqui-peridural combinadas recomendamos que redobrem a atenção no pós-parto, até que futuras pesquisas clínicas avaliem a incidência desta grave complicação relatada.

Prof. Dr. Amaury Sanchez Oliveira, TSA

Dr. Carlos Alberto Figueiredo Côrtes, TSA

Rua Prof. Edgar Atra, 563

Res. Arboreto dos Jequitibás

13105-666 Campinas, SP

\section{Meningitis after Combined Technique for Labor Analgesia. Case Report}

Mr. Editor,

Considering the importance of the authors, the publication "Meningitis after Combined Technique for Labor Analgesia. Case Report", has been very timely, due to generalizations with the risk of rendering banal this technique in Brazil. We do not agree with this, even less with the label of closest to ideal analgesic technique and publicly considering continuous segmental epidural analgesia with local anesthetics associated to opioids as an old-fashioned technique for labor analgesia.

We considered "fantastic" the prompt uterine contraction-induced pain relief after a spinal injection of opioids, followed by excellent analgesia without motor block. However, and for several reasons, the combined technique is not our first choice for the first stage of labor, but rather continuous segmental epidural analgesia with local anesthetics associated to opioids ${ }^{1-3}$. Since $1965,56,925$ analgesias were induced by this method without any case of meningitis. Literature suggests that the combined technique allows for effective analgesia, but is not sufficient to evaluate the analgesic efficacy as compared to epidural with local anesthetics ${ }^{4}$, and that there is a similar incidence of Cesarean sections and instrumental births ${ }^{5}$.

Severe pruritus ${ }^{5}$, arterial hypotension and fetal bradycardia ${ }^{6,7}$, respiratory depression ${ }^{8}$, high sensory block levels even reaching the facial region ${ }^{9}$ are complications and/or side-effects recently described in the literature with the combined technique, although potentially these problems might also be seen with traditional segmental epidural analgesia.
But our major obstacle for the combined technique, which could be indicated for labor analgesia in early cervical dilatation, is still the higher possibility of central nervous system infection with this more invasive technique and which was confirmed by the publication ${ }^{5,10-13}$

According to the report's conclusion, if there were no failures in performing the combined technique, the problem would simply be the risk/benefit ratio of the technique. We suggest to those advocating the combined technique that they should inform their patients about potential risks and benefits of both discussed techniques and, provided the option is the combined spinal/epidural technique, we recommend that post-partum attention should be intensified until further clinical researches evaluate the incidence of this reported severe complication.

\author{
Amaury Sanchez Oliveira, TSA, M.D. \\ Carlos Alberto Figueiredo Côrtes, TSA, M.D. \\ Rua Prof. Edgar Atra, 563 \\ Res. Arboreto dos Jequitibás \\ 13105-666 Campinas, SP
}

\section{REFERÊNCIAS - REFERENCES}

01. Castro LFL, Cavalcanti FS, Hartman AML et al - Analgesia peridural contínua com fentanil no trabalho de parto. Rev Bras Anestesiol, 1992;42:(Supl15):54

02. Castro LFL, Oliveira AS, Sanchez CAS et al - Meperidina peridural no trabalho de parto. Rev Bras Anestesiol, 1993;43: (Supl17):128129.

03. Castro LFL, Oliveira AS, Lira VM et al - Sufentanil peridural no trabalho de parto. Rev Bras Anestesiol, 1994;44:(Supl18):104.

04 . Task Force on obstetrical anesthesia. Practice guidelines for obstetrical anesthesia: a report by the American Society of Anesthesiology. Anesthesiology, 1999;90: 600-611.

05. Bucklin BA, Chestnut DH, Hawkins JL - Intratecal opióides versus epidural local anesthetics for labor analgesia: A meta-analysis. Reg Anesth Pain Med, 2002;27: 23-30.

06. D'Angelo R, Eisennach JC - Severe maternal hypotension and fetal bradycardia after a combined spinal epidural anesthetic. Anesthesiology, 1997;87: 166-168.

07. Eisenach JC - Combined spinal-epidural analgesia in obstetrics. Anesthesiology, 1999;91:299-302.

08. Norris MC, Fogel ST, Haltman B - Intrathecal sufentanil (5vs10 $\mathrm{gg}$ ) for labour analgesia: efficacy and side effects. Reg Anesth, 1998; 23:252-257.

09. Abdou WA, Aveline C, Bonet F - Two additional cases of excessive extension of sensory blockade after intrathecal sufentanil for labor analgesia. International Journal of Obstetric Anesthesia, 2000;9: 48-50.

10. Harding SA, Coolis RE, Morgan BM - Meningitis after combined spinal - extra-dural anaesthesia in obstetrics. Br J Anaesth, 1994;73: 545-547.

11. Wee M, Morgan BM, Collins RE et al - Meningitis after combined spinal - extra-dural anaesthesia in obstetrics. Br J Anaesth, 1995;74: 351.

12. Schroter J, Jamba WAD, Hoffmann V et al - Epidural abscess after combined spinal epidural block. Can J Anaesth, 1997;44: 300-304.

13. Laurila J, Kostamovaara P, Alahuhta S - Spreptococcns salivarius meningitis after spinal anesthesia. Anesthesiology, 1998;89: 1579-1580. 